\title{
Effects of In vitro Atmospheric Ammonia Exposure on Recovery Rate and Luminol- dependent Chemiluminescence of Bovine Neutrophils and Bronchoalveolar Macrophages
}

\author{
Hideo MURATA* and Rieko HORINO \\ Shichinohe Research Unit, National Institute of Animal Health, Shichinohe, Aomori 039-2586, Japan \\ (Received 14 July 1998/Accepted 4 November 1998)
}

ABSTRACT. The effects of atmospheric ammonia, a major pollutant in animal confinement facilities, on bovine neutrophils and bronchoalveolar macrophages were evaluated in vitro. Ammonia exposure at concentrations 50,100 and 200 ppm for one hour impaired recovery rates of neutrophils dose-dependently but enhanced their chemiluminescence activity per cell at lower concentrations (50 and 100 ppm). Macrophages were resistant to the exposure. Their recovery rates and chemiluminescence remained unaffected even at 200 ppm exposure. The present results suggest that ammonia exposure is unfavorable for bovine neutrophils in vitro, and probably in vivo also, in light of causing cell damage and triggering wider inflammatory responses.-KEY wORDs: ammonia exposure, bovine bronchoalveolar macrophage, bovine neutrophil.

Atmospheric ammonia in poultry and swine confinement facilities is known to be a major harmful pollutant in impairing the defense mechanisms of the respiratory tract against pathogens, thereby, aggravating the incidence of respiratory diseases $[2,5]$. In cattle, however, to our knowledge, the effects of ammonia exposure on the animals have been poorly documented.

In a previous study using calves receiving repeated inhalation of ammonia mists [7], our group found a marked increase of chemiluminescence activity, a bactericidal parameter, of bronchoalveolar lavage cells. The cell activation was considered to be due to direct and/or indirect effects of ammonia but the mechanisms remained uninvestigated.

The purpose of the present study was to assess in vitro the effects of ammonia exposure on pro-inflammatory cells in the bovine lung. For this purpose, cell recovery rates and luminol-induced chemiluminescence were evaluated on bovine neutrophils and bronchoalveolar macrophages exposed to various concentrations of atmospheric ammonia.

Neutrophils and bronchoalveolar macrophages were isolated from healthy adult Holstein steers over one year of age $(n=4)$ as previously reported $[7,8]$. The cells were adjusted with an automatic cell counter (Celltac, NihonKoden, Japan) to a concentration of $1 \times 10^{6} / \mathrm{m} l$ in Hanks' buffered salt solution (HBSS, pH 7.4).

Ammonia gas chambers were prepared as follows. In brief, $10 \mu l$ of $6.25,12.5$ or $25 \mathrm{w} / \mathrm{v} \%$ of ammonia solution (Wako, Japan) were mixed with $1 \mathrm{ml}$ of $1 \mathrm{M} \mathrm{NaOH}$ in a glass well with a $25 \mathrm{~mm}$ diameter and a $50 \mathrm{~mm}$ depth to emit 50, 100 or $200 \mathrm{ppm}$ ammonia inside a $1.5 \mathrm{l}$ glass chamber, respectively. The control chamber $(0 \mathrm{ppm})$ used $10 \mu l$ of distilled water in place of ammonia solution. The chambers were kept at $37^{\circ} \mathrm{C}$ and their ammonia levels were

* Present address: Murata, H., Feed Safety Research Division, National Institute of Animal Health, Tsukuba, Ibaraki 3050856, Japan. monitored with a gas detector (Gastec model 801, Japan) before and after the cell exposure. Preliminary experiments have confirmed that ammonia concentration can be kept at each designed level at least for $2 \mathrm{hr}$ at $37^{\circ} \mathrm{C}$.

Two $\mathrm{m} l$ of cell suspension were placed into a siliconcoated polypropylene V-bottom tube with a $25 \mathrm{~mm}$ diameter and a $50 \mathrm{~mm}$ depth in the chamber and exposed to each ammonia concentration for one hour at $37^{\circ} \mathrm{C}$. After the exposure, $\mathrm{pH}$ values of the cell suspensions were measured with a $\mathrm{pH}$ meter (pHBOY-P2, Shin-Dengen, Japan). Ammonia concentrations dissolved in the suspension were estimated with a $\mathrm{pH}$-ammonia concentration standard curve obtained preliminarily. Cell counting was made on each suspension and cell recovery rate at each concentration was calculated as a percentage of cell count ratio (Exposure/ Control). Recovered cells were centrifuged and resuspended in HBSS (pH 7.4) at a concentration of $1 \times 10^{6} / \mathrm{ml}$.

The chemiluminescence assay of the recovered cells was performed as previously described [7]. Briefly, photon emission levels of the cells $\left(2 \times 10^{5}\right.$ cells $)$ in response to phorbol myristate acetate (PMA: Sigma, $1.6 \times 10^{-6} \mathrm{M}$ at final concentration) were evaluated in the presence of luminol (Sigma, $0.5 \mathrm{mg} / \mathrm{m} l$ at final concentration) with a photon-counting luminescence analyzer (Berthold LUMAT LB9505C, Germany). The peak chemiluminescence (cpm) per cell at each ammonia exposure was calculated.

Data were analyzed using analysis of variance and Student's $t$-test. A level of $\mathrm{p}<0.05$ was regarded as significant.

Table 1 shows recovery rates of neutrophils and macrophages exposed to ammonia at concentrations of 50, 100 and $200 \mathrm{ppm}$ for one hour. Neutrophils were sensitive to ammonia exposure and their recovery rates decreased dose-dependently. In contrast, macrophages remained resistant to the exposure. The $\mathrm{pH}$ values and estimated ammonia concentrations (parentheses) in the cell suspensions were at pH8.4-8.6 (1-2 mg/d l), pH8.7-8.9 (2$3 \mathrm{mg} / \mathrm{d} l)$ and $\mathrm{pH} 9.1-9.2(5-6 \mathrm{mg} / \mathrm{d} l)$ at 50, 100 and 200 
ppm exposures, respectively, in both cell groups.

Chemiluminescence per cell at each ammonia exposure is shown in Table 2. Ammonia exposure enhanced neutrophil chemiluminescence per cell by 21 and $14 \%$ on average at concentrations 50 and $100 \mathrm{ppm}$, respectively. At $200 \mathrm{ppm}$, the chemiluminescence level was suppressed by $17 \%$. Macrophage chemiluminescence remained unaffected by the exposure.

Table 3 shows total chemiluminescence of cells at each ammonia exposure, calculated by a formula (chemiluminescence per cell $\times$ cell recovery rate) and expressed as a percentage of control value. It was evident that the total chemiluminescence of neutrophils was impaired in a dose-dependent manner due to ammonia exposure, whereas that of macrophages remained unaffected even at $200 \mathrm{ppm}$ exposure.

In the present in vitro study, bovine neutrophils exposed to atmospheric ammonia decreased their recovery rates dosedependently but enhanced chemiluminescence per cell at lower ammonia concentrations. The decrease of cell recovery rates suggests that numbers of the cells might have been destroyed due to cytotoxic or cytolytic effects of ammonia, such as disturbance of acid-base balance or interference with essential metabolic cycles. Ammonia has also been found to inhibit neutrophil function including chemotaxis, phagocytosis, degranulation and bactericidal activity by alkalizing the intralysosomal $\mathrm{pH}[1,6]$. The enhancement of chemiluminescence per cell at lower ammonia concentrations in this study, however, seems contradictory to those findings.

There is a possible explanation to interpret this

Table 1. Recovery rates of bovine neutrophils and bronchoalveolar macrophages exposed to various concentrations of atmospheric ammonia (\% of Control)

\begin{tabular}{lcccc}
\hline \multirow{2}{*}{ Cell } & \multicolumn{4}{c}{ Ammonia concentration (ppm) } \\
\cline { 2 - 5 } & 0 (Control) & 50 & 100 & 200 \\
\hline Neutrophil & 100 & $75 \pm 11^{\mathrm{a}, \mathrm{b}) *}$ & $70 \pm 18^{\mathrm{b}) *}$ & $59 \pm 11^{\mathrm{b}) *}$ \\
Macrophage & 100 & $94 \pm 14$ & $103 \pm 5$ & $103 \pm 8$ \\
\hline
\end{tabular}

a) Values represent mean \pm standard deviation $(n=4)$.

b) * The mean is significantly different $(\mathrm{p}<0.05)$ from control level. discrepancy. Luminol-dependent chemiluminescence is an indicator of myeloperoxidase(MPO) $-\mathrm{H}_{2} \mathrm{O}_{2}-\mathrm{Cl}^{-}$respiratory burst system of phagocytes [3]. The system is mediated by $\mathrm{NH}_{2} \mathrm{Cl}$ which has been yielded from $\mathrm{NH}_{4}^{+}$, i. e., dissolved $\mathrm{NH}_{3}$ [4]. Suzuki et al. [9] have reported that the presence of $\mathrm{NH}_{3}$ enhanced luminol-dependent chemiluminescence of neutrophils distributed in Helicobacter pylori-induced gastric mucosal injury. It is therefore supposed in this study that the MPO- $\mathrm{H}_{2} \mathrm{O}_{2}-\mathrm{Cl}^{-}$system of bovine neutrophils might have been activated in the presence of $\mathrm{NH}_{4}{ }^{+}$supplied during ammonia exposure. Excessive $\mathrm{NH}_{4}{ }^{+}$, however, seemed to be suppressive on the system as observed in $200 \mathrm{ppm}$ cases.

As compared with neutrophils, bronchoalveolar macrophages were much resistant to ammonia exposure. Their recovery rates and chemiluminescence levels (per cell and total) remained unaffected. Targowski et al. [10] have reported that ammonia added to the culture of guinea pig alveolar macrophages significantly inhibited their phagocytic/bactericidal activities. In this study, however, no such ammonia-related inhibition was evident on bovine macrophages, probably due to the different species of animals or parameters employed. It is not known why bovine macrophages remained less sensitive to ammonia exposure. The cells, because of their longevity and particular role in cell-mediated immunity, such as antigen presentation, may possess stronger ammonia detoxication mechanisms than neutrophils do.

It is still uncertain how bovine pulmonary proinflammatory cells would respond to in vivo ammonia exposure. The present study, however, suggests that ammonia exposure is unfavorable for neutrophils in vitro,

Table 3. Total chemiluminescence of bovine neutrophils and bronchoalveolar macrophages exposed to various concentrations of atmospheric ammonia (\% of Control)

\begin{tabular}{lcccc}
\hline \multirow{2}{*}{ Cell } & \multicolumn{4}{c}{ Ammonia concentration (ppm) } \\
\cline { 2 - 5 } & 0 (Control) & 50 & 100 & 200 \\
\hline Neutrophil & 100 & $90 \pm 20^{\mathrm{a})}$ & $82 \pm 23$ & $48 \pm 14^{\mathrm{b}) *}$ \\
Macrophage & 100 & $91 \pm 11$ & $106 \pm 11$ & $96 \pm 13$ \\
\hline
\end{tabular}

a) Values represent mean \pm standard deviation $(n=4)$.

b) * The mean is significantly different $(\mathrm{p}<0.05)$ from control level.

Table 2. Chemiluminescence per cell of bovine neutrophils and bronchoalveolar macrophages exposed to various concentrations of atmospheric ammonia

\begin{tabular}{lcccc}
\hline Cell & \multicolumn{4}{c}{ Ammonia concentration (ppm) } \\
\cline { 2 - 5 } & 0 (Control) & 50 & 100 & 200 \\
\hline Neutrophil & $130 \pm 58^{\mathrm{a})}$ & $163 \pm 90$ & $153 \pm 91$ & $116 \pm 74$ \\
& $(100)$ & $\left.(121 \pm 19)^{\mathrm{b}}\right)$ & $(114 \pm 22)$ & $(83 \pm 26)$ \\
Macrophage & $14.2 \pm 5.5$ & $13.8 \pm 5.3$ & $14.9 \pm 7.4$ & $13.1 \pm 4.5$ \\
& $(100)$ & $(98 \pm 5)$ & $(103 \pm 13)$ & $(94 \pm 9)$ \\
\hline
\end{tabular}

a) Values represent mean cpm/cell \pm standard deviation $(n=4)$.

b) Values in parentheses represent $\%$ of control level (mean \pm standard deviation, $n=4)$. 
and probably in vivo also, in light of causing cell damage, disturbing their bactericidal oxidation systems and increased inflammatory responses.

\section{REFERENCES}

1. Coppi, M. and Niederman, R. 1989. Biochem. Biophys. Res. Commun. 165: 377-383.

2. Drummond, J. G., Curtis, S. E., Meyer, R. C., Simon, J. and Norton, H. W. 1981. Am. J. Vet. Res. 42: 963-968.

3. Fang, W., Myllys, V. and Sandholm, M. 1997. Am. J. Vet. Res. 58: 601-607.

4. Grisham, M. B., Jefferson, M. M., Melton, D. F. and Tho- mas, E. L. 1984. J. Biol. Chem. 259: 10404-10413.

5. Julian, R. J. 1991. pp. 863-884. In: Diseases of Poultry, 9th ed. (Calnek, B. W., Banes, H. J., Beard, C. W., Reid, W. W. and Yoder, H. W. Jr. eds.), Iowa State Univ. Press, Ames.

6. Klempner, M. S. and Styrt, B. 1983. J. Clin. Invest. 72: 17931800 .

7. Murata, H. 1997. J. Vet. Med. Sci. 59: 141-142.

8. Murata, H. and Hirose, H. 1991. Br. Vet. J. 147: 455-462.

9. Suzuki, M., Miura, S., Suematsu, M., Fukushima, D., Kurose, I., Suzuki, H., Kai, A., Kudoh, Y., Ohashi, M. and Tsuchiya, M. 1992. Am. J. Physiol. 263: G719-725.

10. Targowski, S. P., Klucinski, W., Babiker, S. and Nonnecke, B. J. 1984. Infect. Immun. 43: 289-293. 